\title{
Downregulation of SMP30 in senescent human lens epithelial cells
}

\author{
SHUNING LI, XI CHEN, WEIXIA LAI, MEIXIA HU, XIN ZHONG, SHAOJIAN TAN and HAO LIANG
}

Department of Ophthalmology, First Affiliated Hospital of Guangxi Medical University, Nanning, Guangxi 530021, P.R. China

Received September 7, 2016; Accepted May 23, 2017

DOI: $10.3892 / \mathrm{mmr} .2017 .7106$

\begin{abstract}
Senescence marker protein 30 (SMP30) has been reported to serve antiapoptotic and antioxidant roles, as well as roles in $\mathrm{Ca}^{2+}$ regulation, and may be involved in the occurrence and development of cataract. The present study aimed to investigate the expression of SMP30 in senescent human lens epithelial cells (HLECs) and explored the relationship between SMP30 and aging. SRA01/04 cells, a HLEC line, were treated with $\mathrm{H}_{2} \mathrm{O}_{2}$ to mimic aging, and cell morphological changes were observed by microscopy and cell activity was examined by MTT assay, senescence-associated- $\beta$-galactosidase (SA- $\beta$-Gal) staining and cell cycle analysis. The expression of SMP30 mRNA and protein was measured by reverse transcription-quantitative polymerase chain reaction (RT-qPCR) and western blotting. Following prolonged low-dose $\mathrm{H}_{2} \mathrm{O}_{2}$ exposure cells exhibited senescence-related morphological changes, reduced growth activity, increased SA- $\beta$-Gal positive staining and cell cycle arrest in the $\mathrm{S}$ and G2/M phases. SMP30 mRNA expression levels were significantly downregulated following exposure to 75 and $100 \mu \mathrm{M} \mathrm{H}_{2} \mathrm{O}_{2}$, and the protein expression levels in the same groups were decreased by $>6$-fold compared with the control untreated cells. However, no significant change was observed in SMP30 expression in the 25 and $50 \mu \mathrm{M} \mathrm{H}_{2} \mathrm{O}_{2}$ exposure groups. These results suggest that, in the early stage of senescence induced by $\mathrm{H}_{2} \mathrm{O}_{2}$-mediated chronic oxidative stress, there may be no significant change in SMP30 expression, but when the oxidative stress increases and senescence is aggravated, SMP30 may be significantly downregulated in the senescent HLECs. The present study indicates that SMP30 may be an important factor involved in the aging process of HLECs and the development of cataract.
\end{abstract}

\section{Introduction}

Senescence marker protein 30 (SMP30) is a novel type of calcium binding protein that does not possess a typical $\mathrm{Ca}^{2+}$

Correspondence to: Dr Hao Liang, Department of Ophthalmology, First Affiliated Hospital of Guangxi Medical University, 6 Shuangyong Road, Nanning, Guangxi 530021, P.R. China

E-mail: gxnn_lianghao@163.com

Key words: senescence marker protein 30, oxidative stress, aging, human lens epithelial cells, cataract binding EF-motif, and that was first isolated as a downregulated protein in aging rat livers in an androgen-independent manner (1). It is localized in the plasma membrane, nucleus, microsomes and mitochondria of different cell types. Following cloning and analysis of the gene encoding for it, SMP30 was demonstrated to be a complex molecule composed of 442 amino acids and $34 \mathrm{kDa}(2,3)$. It is widely expressed in various human tissues, including liver, kidney, breast, brain, stomach, lung, ovary, testis, skin, prostate, epididymis and it is highest expressed in liver and kidney $(4,5)$. It has been reported as upregulated in human prostate and breast cancers, and overexpression of SMP30 has been demonstrated to alter the expression of tumor related-genes, including MYC proto-oncogene, HRas proto-oncogene, SRC proto-oncogene, tumor protein $\mathrm{p} 53$, and RB transcriptional corepressor 1; SMP30 inhibits the expression of oncogenes and enhances the transcription of anti-oncogenes, and thus has anti-tumor activity $(6,7)$. In addition, SMP30 expression in cancer is significantly higher than normal tissue, and its high expression may be associated with the early stages of carcinogenesis and may be a manifestation of the cell protective mechanisms (8). These previous findings suggest a protective role of SMP30 against cancer development.

SMP30 has been reported to serve important roles in maintaining $\mathrm{Ca}^{2+}$ homeostasis and signaling via activating enzymes and the $\mathrm{Ca}^{2+}$ pump $(9,10)$. SMP30 also prevents apoptosis induced by $\mathrm{Ca}^{2+}$ influx, as well as exhibits a protective effect against apoptosis induced by other signaling pathways (11). Previous studies have demonstrated that SMP30 can decrease reactive oxygen species levels (12), reduce the oxidative stress damage induced by peroxide and inhibit antioxidant enzyme activity (13-15). Other reports have demonstrated that SMP30 may be involved in the inhibition of DNA and RNA synthesis through regulation of protein kinases and protein phosphatases (16-19). SMP30 exhibits a suppressive effect on cellular proliferation in rat liver and kidney cells, and may be involved in proliferation-related functions in the cell nucleus $(20,21)$. More recently, it was reported that it also involved in the cellular inflammatory response, and that its anti-inflammatory and antioxidant functions may be mediated by activation of the nuclear factor- $\kappa$ B pathway (22). In addition, SMP30 was reported to negatively regulate abnormal lipid accumulation and decrease glucose tolerance in the liver during the normal aging process (23-26).

As a result of its many functions, SMP30 has intrigued researchers regarding its potential as a novel anti-aging 
molecule. SMP30 is broadly expressed in various human tissues, however, its role in ophthalmic diseases remains unclear. Our previous study reported that expression of SMP30 in patients with cataract was higher than normal subjects, while it was significantly lower in patients $>60$ years old compared with patients $\leq 60$ (27). The present study aimed to examine whether expression of SMP30 is age-related in the human lens. In order to investigate the roles of SMP30 in human lens epithelial cells, prolonged exposure of cells to low doses of hydrogen peroxide $\left(\mathrm{H}_{2} \mathrm{O}_{2}\right)$ was used as an in vitro model to mimic senescence, and the expression of SMP30 was detected as a function of aging.

\section{Materials and methods}

Cell culture. The human lens epithelial cell line (SRA01/04) was obtained from Guangzhou JiNiu Biotechnology Co. Ltd. (Guangzhou, China). SRA01/04 cells were cultured in Dulbecco's modified Eagle's medium (DMEM), supplemented with $10 \%$ fetal bovine serum (both from Gibco; Thermo Fisher Scientific, Inc., Waltham, MA, USA) at $37^{\circ} \mathrm{C}$ and in a humidified atmosphere containing $5 \% \mathrm{CO}_{2}$. When the cells reached $\sim 80 \%$ confluency, they were treated with $0.25 \%$ trypsin solution, centrifuged (106 x g, $5 \mathrm{~min}$, room temperature) and plated for subculture or frozen for storage.

In vitro SRA01/04 aging model. Cells were treated with a concentration gradient of freshly-prepared $\mathrm{H}_{2} \mathrm{O}_{2}(0-150 \mu \mathrm{M})$ to mimic aging in vitro. Prolonged exposure to $\mathrm{H}_{2} \mathrm{O}_{2}$ to stimulate senescence was conducted as previously described (28). Cells cultured in the same medium without $\mathrm{H}_{2} \mathrm{O}_{2}$ served as the control group. The medium was changed with fresh $\mathrm{H}_{2} \mathrm{O}_{2}$-containing medium every 3 days for a total of 2 weeks. All experiments were performed with cells of passages 4-6 to avoid the influence of natural senescence.

Observation of cell morphology. Cell morphology observation was used as a method to evaluate cell senescence. Treated cells were observed by light microscopy (Olympus Corporation, Tokyo, Japan) at magnification, x20.

MTT cell viability assay. A growth curve was performed to examine cell viability over time in the experimental groups. SRA01/04 cells were seeded at $1 \times 10^{3}$ cells/well in 96-well plates and incubated overnight with normal medium. The following day, cells were treated with a concentration gradient $\mathrm{H}_{2} \mathrm{O}_{2}$ for different periods of time $(0,1,3,5,7,9,12$ and 15 days), with 5 replicates for each experimental group and for each time point. When reaching the stated time point, cells were incubated for $4 \mathrm{~h}$ at $37^{\circ} \mathrm{C}$ with $20 \mu \mathrm{l} \mathrm{MTT}(5 \mathrm{mg} / \mathrm{ml}$; Sigma-Aldrich; Merck KGaA, Darmstadt, Germany), then the medium was removed and $150 \mu \mathrm{l}$ DMSO was added to dissolve the formazan products in each well. Absorbance was measured at $570 \mathrm{~nm}$ using a microplate reader (Thermo Fisher Scientific, Inc.).

Senescence-associated- $\beta$-galactosidase (SA- $\beta$-Gal) staining assay. A SA- $\beta$-gal staining kit (Beyotime Institute of Biotechnology, Haimen, China) was used, according to the manufacturer's instructions. SRA01/04 were seeded on 6-well plates and treated with low doses of $\mathrm{H}_{2} \mathrm{O}_{2}$ as aforementioned. At stated time points, and after washing with PBS, cells were incubated with $1 \mathrm{ml}$ fixing solution at room temperature for 15 min, washed three times with PBS, and then incubated with $1 \mathrm{ml}$ freshly prepared cell staining solution at $37^{\circ} \mathrm{C}$ overnight (without $\mathrm{CO}_{2}$ ). Stained cells were analyzed by light microscopy by observing at least 10 random fields for each sample and manually quantifying the $\%$ of SA- $\beta$-gal positive cells.

Cell cycle assay. Following the 2-week treatment period, cells were washed once in PBS and a cell suspension of $1 \times 10^{6}$ cells $/ \mathrm{ml}$ was fixed in $70 \%$ cold ethanol at $4^{\circ} \mathrm{C}$ for $12 \mathrm{~h}$. The cells were then washed with PBS and incubated with $100 \mu 1 \mathrm{RNase}$ A for $30 \mathrm{~min}$ at $37^{\circ} \mathrm{C}$. Finally, cells were stained with $400 \mu \mathrm{l}$ propidium iodide in the dark for $30 \mathrm{~min}$ at $4^{\circ} \mathrm{C}$. Cell cycle analysis was performed using a FACScan flow cytometer equipped with CFlow Plus version 1.0.264.15 (both from BD Biosciences, San Jose, CA, USA).

Reverse transcription-quantitative polymerase chain reaction $(R T-q P C R)$. Total RNA was isolated from cultured cells using TRIzol reagent (Thermo Fisher Scientific, Inc.) and converted into cDNA using the PrimeScript RT reagent kit with gDNA Eraser (cat no. RR047A; Takara Bio, Inc., Otsu, Japan), according to the manufacturer's instructions. The concentration of total RNA was measured using a NanoDrop 2000 (Thermo Fisher Scientific, Inc.). qPCR was performed on a LightCycler 480 real-time PCR system (Roche Diagnostics, Indianapolis, IN, USA) with the SYBR Premix Ex Taq II kit (cat no. RR820A. Takara Bio, Inc.). The primers used for qPCR were: SMP30, sense 5'-CCGTGGATGCCTTTGACT ATGAC-3' and antisense 5'-GTAACAGGCCACCCAGAG CTTC-3'; GAPDH, sense 5'-GCACCGTCAAGGCTGAGA AC-3' and antisense 5'-TGGTGAAGACGCCAGTGGA-3'. The thermocycling conditions were set up according to the manufacturer's instructions: $95^{\circ} \mathrm{C}$ for $30 \mathrm{sec}$, followed by 40 cycles at $95^{\circ} \mathrm{C}$ for $5 \mathrm{sec}$ and $60^{\circ} \mathrm{C}$ for $30 \mathrm{sec}$, followed by a melting curve analysis of 1 cycle at $95^{\circ} \mathrm{C}$ for $5 \mathrm{sec}, 60^{\circ} \mathrm{C}$ for $1 \mathrm{~min}$ and $50^{\circ} \mathrm{C}$ for $30 \mathrm{sec}$. The melting curve analysis confirmed that the amplification contained no primer dimers or non-specific PCR products. The experiment was repeated six independent times in triplicates and the results were calculated using $2^{-\Delta \Delta C q}$ method (29)

Protein extraction and western blot analysis. Cells were extracted using lysis buffer (Beyotime Institute of Biotechnology) at $4^{\circ} \mathrm{C}$ for $30 \mathrm{~min}$. The concentration of total protein was measured by bicinchoninic acid assay (Beyotime Institute of Biotechnology). Protein samples (50 $\mu \mathrm{g} /$ well) were boiled, separated on $10 \%$ sodium dodecyl sulfate polyacrylamide gel, and then electrophoretically transferred onto polyvinylidene fluoride membranes. Blots were subsequently incubated for $1 \mathrm{~h}$ at room temperature with blocking buffer, which contained $5 \%(\mathrm{w} / \mathrm{v})$ skimmed milk powder in TBS $+0.1 \%$ Tween-20 (TBST). The blots were subsequently incubated with antibodies targeting SMP30 (cat no. ab67336; dilution 1:1,000; Abcam, Cambridge, MA, USA) and $\beta$-actin (cat. no. 12262; dilution 1:1,000; Cell Signaling Technology, Inc., Danvers, MA, USA) overnight at $4^{\circ} \mathrm{C}$. Blots were then 
washed with TBST for $30 \mathrm{~min}$. All blots were incubated with a IRDye 680RD goat anti-mouse secondary antibody (cat. no. 926-68070; dilution 1:15,000; Li-Cor Biosciences, Lincoln, NE, USA) for $2 \mathrm{~h}$ at room temperature. Following washing with TBST, protein signals were measured using the Odyssey Infrared Imaging System v3.0 (Li-Cor Biosciences). The experiment was repeated six independent times in triplicates.

Statistical analysis. All experiments were repeated at least three times. Statistical analysis was performed with SPSS 17.0 software (SPSS, Inc., Chicago, IL, USA). Results were expressed as mean \pm standard deviation. Differences between groups were analyzed for significance by one-way analysis of variance followed by Fisher's least significant difference test. $\mathrm{P}<0.05$ was considered to indicate a statistically significant difference.

\section{Results}

Cell morphology changes in SRA01/04 cells following prolonged low-dose exposure of $\mathrm{H}_{2} \mathrm{O}_{2}$. Following observation by microscopy, no significant changes in cell morphology were observed between the untreated control group and the $25 \mu \mathrm{M} \mathrm{H}_{2} \mathrm{O}_{2}$ group (Fig. 1). Exposure to 50 and $75 \mu \mathrm{M} \mathrm{H}_{2} \mathrm{O}_{2}$ resulted in somewhat enlarged cell morphology and a slightly decreased cell density in 5-7 days (Fig. 1). Continuous culture for two weeks at $75 \mu \mathrm{M} \mathrm{H}_{2} \mathrm{O}_{2}$ resulted in a markedly decreased cell growth and a flattened cell morphology with accumulation of granular cytoplasmic inclusions compared with the control group (Fig. 1). At the dose of 100 and $125 \mu \mathrm{M} \mathrm{H}_{2} \mathrm{O}_{2}$, cells appeared shrank, elongated and a larger number of floating cells were observed, while after 10 days cells gradually became detached and disrupted (Fig. 1). At $150 \mu \mathrm{M} \mathrm{H}_{2} \mathrm{O}_{2}$ exposure, cells were all dead in the first 3 days (Fig. 1).

Prolonged exposure to 50, 75 and $100 \mu \mathrm{M} \mathrm{H}_{2} \mathrm{O}_{2}$ induces cell senescence. SA- $\beta-$ Gal staining is routinely used to detect senescent cells, and positive staining appears as cytoplasmic blue granular coloring under microscopic observation. As illustrated in Fig. 2A, positively stained cells appeared following exposure of the cells to certain doses of $\mathrm{H}_{2} \mathrm{O}_{2}$ for two weeks. There were nearly no positive cells in the control untreated group $(2.15 \pm 0.68 \%)$ and the $\%$ of positive cells observed increased in a dose-dependent manner compared with the control group (Fig. 2B). Only a few positive cells appeared in the $25 \mu \mathrm{M}$ group $(13.37 \pm 3.50 \%$; Fig. $2 \mathrm{~B})$ and $50 \mu \mathrm{M}$ group $(40.23 \pm 6.58 \%$; Fig. $2 \mathrm{~B})$. The $\%$ of positive cells increased dramatically in the $75 \mu \mathrm{M}$ group $(90.48 \pm 6.80 \%$; Fig. 2B) and $100 \mu \mathrm{M}$ group (92.10 $\pm 3.84 \%$; Fig. 2B). In the 125 and $150 \mu \mathrm{M}$ groups, although positive staining was observed, most cells appeared non-viable following the two-week exposure (Fig. 2A).

Prolonged exposure to $75 \mathrm{\mu M} \mathrm{H}_{2} \mathrm{O}_{2}$ induces growth inhibition . Cell growth was evaluated by MTT assay over the period of 15 days. Untreated control SRA01/04 cells grew slowly on days 1-3 of culture, while at day 5 , cell growth turned to a logarithmic phase (Fig. 2C). In the $\mathrm{H}_{2} \mathrm{O}_{2}$ exposure groups, the $25 \mu \mathrm{M}$ group exhibited no effect on cell survival compared with the control group (Fig. 2C). In the $50 \mu \mathrm{M}$ group, the

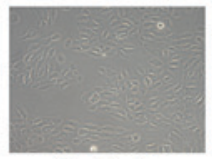

Control

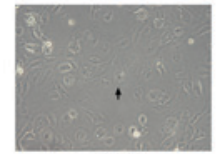

100

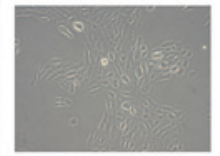

25

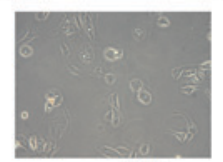

125

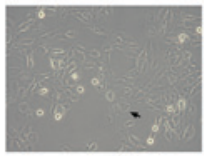

50

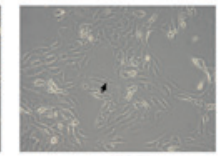

75
Figure 1. Prolonged $\mathrm{H}_{2} \mathrm{O}_{2}$ exposure results in senescence-related morphological changes. SRA01/04 were treated for two weeks with various concentrations of $\mathrm{H}_{2} \mathrm{O}_{2}(0-150 \mu \mathrm{M})$, and then cell morphology was examined by microscopy. Arrows denote senescent cells, which appear enlarged, flattened, and with accumulation of granular cytoplasmic inclusions. Magnification, $\mathrm{x} 2 \mathrm{O} . \mathrm{H}_{2} \mathrm{O}_{2}$, hydrogen peroxide.

growth curve declined compared with control (Fig. 2C). The growth curve of the $75 \mu \mathrm{M}$ group exhibited a small increase in the first 5 days of exposure, but then cell growth was arrested and maintained in a low level for the rest of the treatment (Fig. 2C). Finally, in the 100,125 and $150 \mu \mathrm{M}$ groups, growth declined substantially compared with control and was almost at zero for the whole duration of the experiment (Fig. 2C).

Prolonged exposure to $\mathrm{H}_{2} \mathrm{O}_{2}$ induces cell cycle arrest. Cell cycle analysis (Table I and Fig. 3A) was performed to examine the proportion of cells in each phase of the cell cycle. In the 25, 50,75 and $100 \mu \mathrm{M}$ groups, the $\%$ of cells in the G0/G1 phase were decreased significantly compared with the control group (Fig. 3B). Meanwhile, the 50, 75 and $100 \mu \mathrm{M}$ groups exhibited significantly higher $\%$ of cells in the S phase compared with the control group (Fig. 3B), as well as a significant increase in the $\mathrm{G} 2 / \mathrm{M}$ cell populations compared with the control group (Fig. 3B). The 125 and $150 \mu \mathrm{M}$ groups were all cell debris (Fig. 3A). The cell proliferation index (PI), which was calculated as the sum of the $\%$ of cells in the S plus G2/M phases, was significantly increased in the 25,50,75 and $100 \mu \mathrm{M}$ groups compare with the control group (Fig. 3C). The results demonstrated that prolonged exposure to 50, 75 and $100 \mu \mathrm{M} \mathrm{H}_{2} \mathrm{O}_{2}$ disrupted the normal cell cycle progress, arrested SRA01/04 cells in the $S$ and G2/M phases and increased the PI value compared with control.

These above experiments were employed to evaluate cell senescence in response to prolonged exposure to $\mathrm{H}_{2} \mathrm{O}_{2}$. Based on the results of the present study, treatment with $75 \mu \mathrm{M}$ $\mathrm{H}_{2} \mathrm{O}_{2}$ for two weeks resulted in chronic oxidative stress and simulated aging of SRA01/04 cells in vitro, without causing cell death. Therefore, the dose of $75 \mu \mathrm{M} \mathrm{H}_{2} \mathrm{O}_{2}$ was selected to induce in vitro aging for the remainder of the experiments. The doses of 25, 50 and $100 \mu \mathrm{M}$ were used to investigate the different grades of chronic oxidative stress.

SMP30 expression is downregulated in senescent SRA01/04 cells. In order to investigate the expression of SMP30 in senescent HLECs, SRA01/04 were exposed to $\mathrm{H}_{2} \mathrm{O}_{2}$ for two weeks to simulate senescence induced by chronic oxidative stress, then mRNA and protein expression levels were 
Table I. Cell cycle analysis of SRA01/04 cells following $\mathrm{H}_{2} \mathrm{O}_{2}$ exposure in vitro.

\begin{tabular}{rcrrr}
\hline $\mathrm{H}_{2} \mathrm{O}_{2}(\mu \mathrm{M})$ & $\mathrm{GO} / \mathrm{G} 1(\%$ of cells $)$ & $\mathrm{S}(\%$ of cells $)$ & G2/M $(\%$ of cells $)$ & PI $(\%$ of cells $)$ \\
\hline 0 & $79.41 \pm 4.01$ & $8.74 \pm 1.88$ & $8.74 \pm 1.88$ & $18.27 \pm 1.84$ \\
25 & $68.00 \pm 3.35$ & $11.35 \pm 3.71$ & $20.60 \pm 1.12$ & $31.94 \pm 3.51$ \\
50 & $61.25 \pm 5.30$ & $13.65 \pm 3.45$ & $21.58 \pm 3.56$ & $36.50 \pm 2.59$ \\
75 & $46.81 \pm 3.59$ & $23.59 \pm 4.05$ & $25.18 \pm 2.11$ & $51.07 \pm 1.41$ \\
100 & $45.58 \pm 3.29$ & $21.02 \pm 2.23$ & $27.48 \pm 2.40$ & $51.53 \pm 1.68$ \\
\hline
\end{tabular}

Data are presented as mean \pm standard deviation from four independent repeats. PI represents the sum of the $\%$ of cells in the $\mathrm{S}$ and $\mathrm{G} 2 / \mathrm{M}$ phases. $\mathrm{H}_{2} \mathrm{O}_{2}$, hydrogen peroxide; PI, proliferation index.

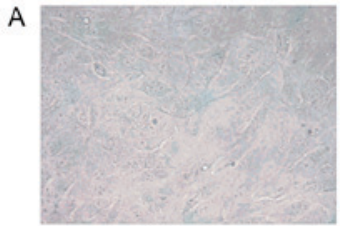

Control

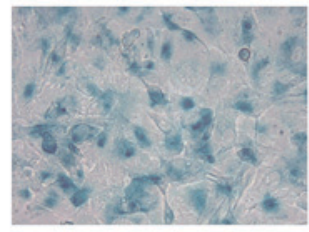

100

B

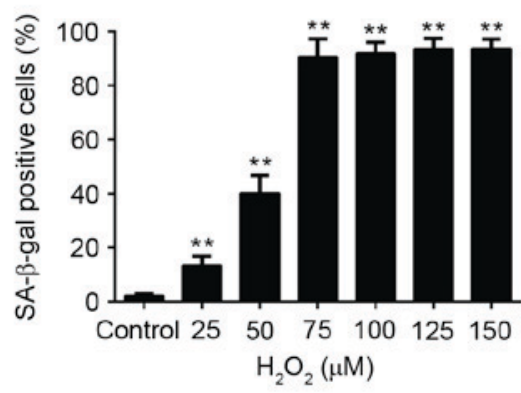

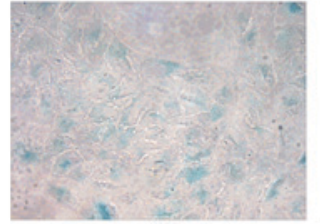

50

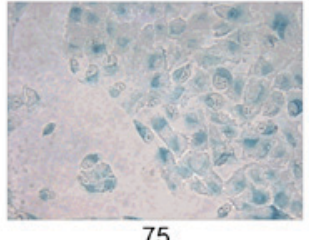

75

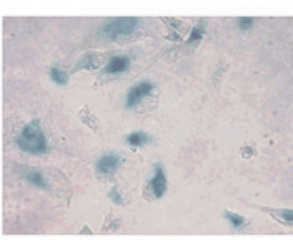

125

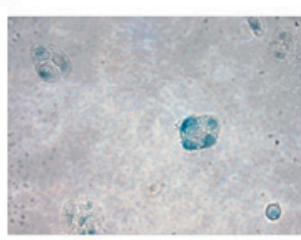

150

C

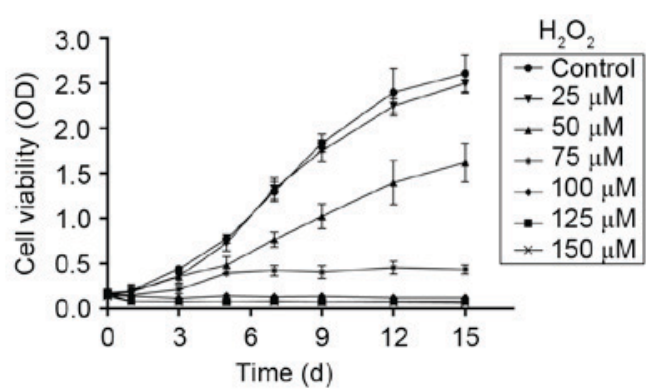

Figure 2. Characteristics of senescent SRA01/04 cells induced by prolonged low-dose exposure to $\mathrm{H}_{2} \mathrm{O}_{2}$. (A) Representative images of SA- $\beta$-Gal staining from SRA01/04 cells treated with $0-150 \mu \mathrm{M} \mathrm{H}_{2} \mathrm{O}_{2}$ for two weeks. Magnification, $\mathrm{x} 20$. (B) Quantification of SA- $\beta$-Gal positive cells ( $\mathrm{n}=10$ ). (C) Growth curve as measured by the MTT assay $(n=6)$. Data were presented as mean \pm standard deviation. ${ }^{* *} \mathrm{P}<0.01$ vs. control group. $\mathrm{H}_{2} \mathrm{O}_{2}$, hydrogen peroxide; $\mathrm{SA}-\beta-\mathrm{Gal}$, senescence-associated- $\beta$-galactosidase; OD, optimal density.

examined by RT-qPCR and western blotting. RT-qPCR analysis demonstrated that expression of SMP30 mRNA levels were significantly decreased following $\mathrm{H}_{2} \mathrm{O}_{2}$ exposure compared with the control group, to $0.7,0.74,0.5$ and 0.4 -fold of the control in the $25,50,75,100 \mu \mathrm{M} \mathrm{H}_{2} \mathrm{O}_{2}$ groups, respectively (Fig. 4A). However, there was no difference between the 25 and $50 \mu \mathrm{M} \mathrm{H}_{2} \mathrm{O}_{2}$ groups ( $\left.\mathrm{P}=0.921\right)$, and no difference between the 75 and $100 \mu \mathrm{M} \mathrm{H}_{2} \mathrm{O}_{2}$ groups $(\mathrm{P}=0.053)$. As presented in Fig. 4B, at the protein level, SMP30 expression was no different in the $25 \mu \mathrm{M}$ group $(\mathrm{P}=0.695)$ and the $50 \mu \mathrm{M}$ group $(\mathrm{P}=0.126)$ compared with control. However, SMP30 expression was significantly decreased by $>6$-fold in the 75 and $100 \mu \mathrm{M}$ groups compared with the control (Fig. 4B). No significant difference was observed in the SMP30 protein expression between the 75 and $100 \mu \mathrm{M}$ groups (Fig. 4B).

\section{Discussion}

SMP30 has great potential as a novel anti-aging factor as it serves important roles in maintaining $\mathrm{Ca}^{2+}$ homeostasis, preventing apoptosis, and reducing oxidative stress damage $(1,9)$. The occurrence and development of cataract is complicated owing to various factors, and the exact pathogenesis of cataract is not clearly understood, but it is thought to be closely related to calcium disorders, oxidative stress and apoptosis of HLECs (30-33). With aging or other external factors, changes can happen in these biological functions of HLECs and they can lead to the occurrence of cataract. Hammond et al (34), through analysis of patients with age-related cataract (ARC), reported that age was an important risk factor of ARC. In addition, age was confirmed 


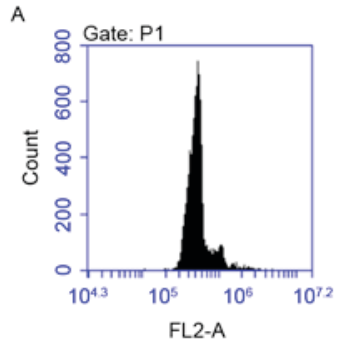

ctrl

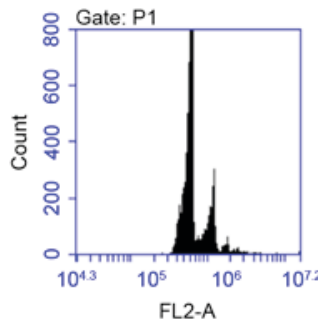

25

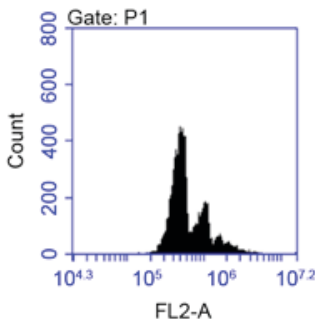

50

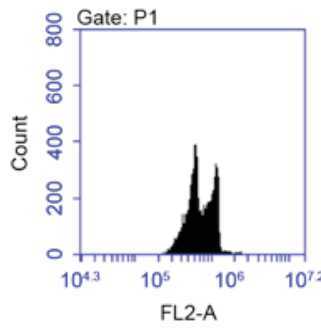

75

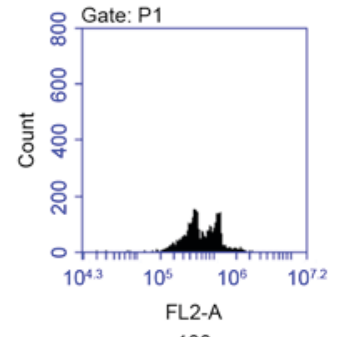

100

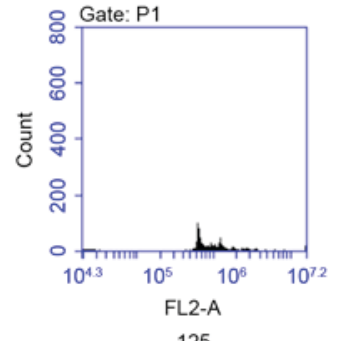

125

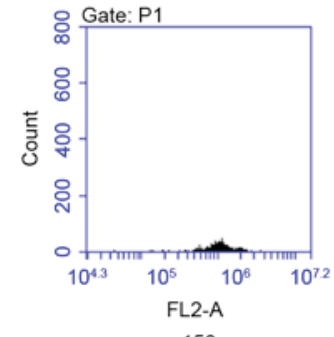

150
B

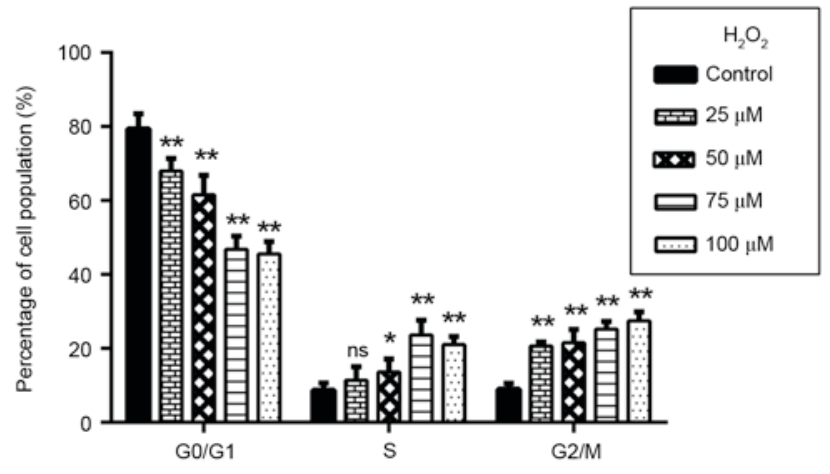

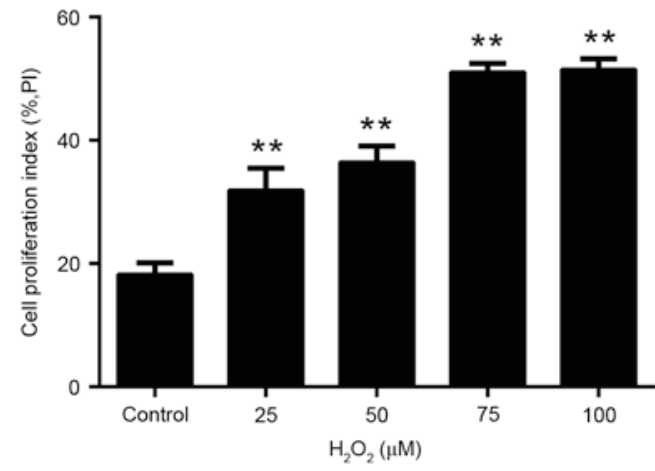

Figure 3. Cell cycle analysis of SRA01/04 cells induced by prolonged low-dose exposure to $\mathrm{H}_{2} \mathrm{O}_{2}$. (A) Representative plots from flow cytometry analysis of cell cycle distribution in SRA01/04 cells treated with 0-150 $\mu \mathrm{M} \mathrm{H}_{2} \mathrm{O}_{2}$ for two weeks. (B) Quantification of \% of cells in each cell cycle phase. (C) The cell proliferation index was calculated as the sum of the $\%$ cells in the $\mathrm{S}$ and $\mathrm{G} 2 / \mathrm{M}$ phases. Data were presented as mean \pm standard deviation ( $\mathrm{n}=4$ ). ${ }^{*} \mathrm{P}<0.05$ and ${ }^{* *} \mathrm{P}<0.01$ vs. control group. $\mathrm{H}_{2} \mathrm{O}_{2}$, hydrogen peroxide; Ctrl, control; ns, not significant.

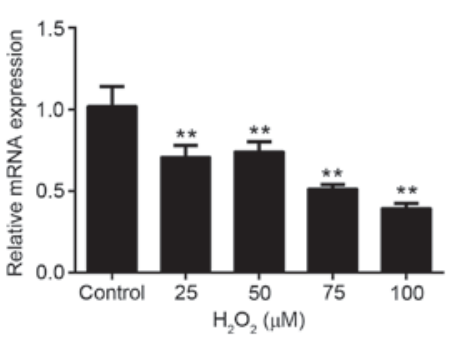

B

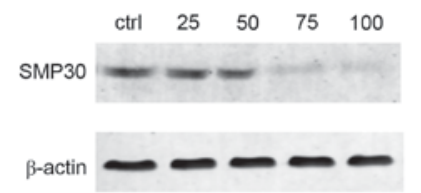

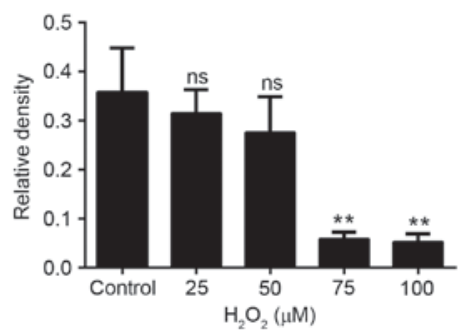

Figure 4. SMP30 expression is downregulated by prolonged low-dose exposure to $\mathrm{H}_{2} \mathrm{O}_{2}$. SRA01/04 cells were treated with 0-150 $\mu \mathrm{M} \mathrm{H}_{2} \mathrm{O}_{2}$ for two weeks. (A) SMP30 mRNA expression levels were analyzed by reverse transcription-quantitative polymerase chain reaction. (B) SMP30 protein expression levels were analyzed by western blotting. $\beta$-actin was used as the internal control. Data were presented as mean \pm standard deviation ( $=6$ ). ${ }^{* *} \mathrm{P}<0.01$ vs. control group. $\mathrm{H}_{2} \mathrm{O}_{2}$, hydrogen peroxide; $\mathrm{Ctrl}$, control; ns, not significant. 
to be directly related to the development of ARC, while other factors had no significant correlation (35). Potential anti-aging intervention in HLECs may therefore be especially important for the development of ARC. In recent years, SMP30 was demonstrated to serve an important role in anti-aging, as it was determined that the expression level of SMP30 gradually decreased in aging human liver cells (35). SMP30 was also demonstrated to be involved in cellular senescence and SMP30 knock-out mice were susceptible to cataract (36). Our previous report demonstrated that SMP30 is expressed in human lens capsule epithelial cells, mainly in the cytoplasm and less in the nucleus, the expression of SMP30 in patients with cataract was higher than healthy subjects, but in cataract patients of age $>60$ it was significantly lower than patients of age $\leq 60$, suggesting that SMP30 expression may be closely related to the development of cataract (27). Whether SMP30 is involved the process of aging in HLECs has not been yet reported.

To explore the relationship between SMP30 and aging, a low-dose prolonged exposure to $\mathrm{H}_{2} \mathrm{O}_{2}$ was used to induce chronic oxidative stress and senescence in cells. $\mathrm{H}_{2} \mathrm{O}_{2}$ is one of the main oxides in the human lens. The concentration of $\mathrm{H}_{2} \mathrm{O}_{2}$ is $\sim 20-30 \mu \mathrm{M}$ in the normal lens and aqueous humor. However, in the cataract lens, the concentration of $\mathrm{H}_{2} \mathrm{O}_{2}$ is significantly increased by $\sim 2-7$-fold, and even increased to 30 -fold in aqueous humor $(37,38)$. In addition, various studies using in vitro lens cell culture and animal models have reported that $\mathrm{H}_{2} \mathrm{O}_{2}$ can induce cataract $(39,40)$. Therefore, in the present study, $\mathrm{H}_{2} \mathrm{O}_{2}$ was selected to induce senescent HLECs and observe the expression of SMP30.

Prolonged low-dose exposure to $\mathrm{H}_{2} \mathrm{O}_{2}$ is the most commonly used method for inducing senescence in cells in vitro, due to its common mechanisms with pathological aging (41-44). In the present study, HLECs were exposure to $\mathrm{H}_{2} \mathrm{O}_{2}$ over two weeks, causing chronic oxidative stress, to induce cell senescence and to simulate aging. Then the senescent state of the cells was confirmed by morphological observations, declined growth, increased SA- $\beta-$ Gal positive staining and cell cycle arrest. These results confirmed that cellular proliferation was inhibited and senescence occurred. Using this in vitro model, the expression level of SMP30 were measured at the mRNA and the protein level. Compared with the control group, SMP30 mRNA and protein were significantly decreased in the 75 and $100 \mu \mathrm{M}$ groups, but no significant changes were observed in the 25 and $50 \mu \mathrm{M}$ groups on the protein level. These results suggest that in the early stages of senescence induced by $\mathrm{H}_{2} \mathrm{O}_{2}$, there was no significant change of SMP30 protein compared with normal cells, but with the effect of oxidative stress increasing and senescence aggravated as $\mathrm{H}_{2} \mathrm{O}_{2}$ concentration raised, SMP30 was downregulated in senescent HLECs. SMP30 may therefore be an important factor involved in the HLEC aging process and the development of cataract.

To the best of our knowledge, the present study is the first to link SMP30 expression with aging HLECs, although the exact function and mechanism of SMP30 in the lens remains unclear and further studies will be needed to elucidate this. There are various limitations in this study. For example, measuring SMP30 expression at different time points during the senescence process would give more dynamic information on the role of SMP30 in HLEC senescence. Further studies are warranted to fully understand the anti-aging function of SMP30 and its potential in the development and prevention of cataract.

\section{Acknowledgements}

The authors would like to thank Dr Hao Liang for the instruction of experiments. The present study was supported by a grant from the National Natural Science Foundation of China (grant no. 81360146).

\section{References}

1. Fujita T, Uchida K and Maruyama N: Purification of senescence marker protein-30 (SMP30) and its androgen-independent decrease with age in the rat liver. Biochim Biophys Acta 1116: 122-128, 1992.

2. Fujita T, Shirasawa T and Maruyama N: Isolation and characterization of genomic and cDNA clones encoding mouse senescence marker protein-30 (SMP30). Biochim Biophys Acta 1308: 49-57, 1996.

3. Fujita T, Shirasawa T and Maruyama N: Expression and structure of senescence marker protein-30 (SMP30) and its biological significance. Mech Ageing Dev 107: 271-280, 1999.

4. Feng D, Kondo Y, Ishigami A, Kuramoto M, Machida T and Maruyama N: Senescence marker protein-30 as a novel antiaging molecule. Ann N Y Acad Sci 1019: 360-364, 2004.

5. Maia C, Santos C, Schmitt F and Socorro S: Regucalcin is under-expressed in human breast and prostate cancers: Effect of sex steroid hormones. J Cell Biochem 107: 667-676, 2009.

6. Tsurusaki Y and Yamaguchi M: Overexpression of regucalcin modulates tumor-related gene expression in cloned rat hepatoma H4-II-E cells. J Cell Biochem 90: 619-626, 2003.

7. Tsurusaki Y and Yamaguchi M: Role of regucalcin in liver nuclear function: binding of regucalcin to nuclear protein or DNA and modulation of tumor-related gene expression. Int J Mol Med 14: 277-281, 2004.

8. Scott SH and Bahnson BJ: Senescence marker protein 30: Functional and structural insights to its unknown physiological function. Biomol Concepts 2: 469-480, 2011.

9. Fujita T, Inoue H, Kitamura T, Sato N, Shimosawa T and Maruyama N: Senescence marker protein-30 (SMP30) rescues cell death by enhancing plasma membrane $\mathrm{Ca}(2+)$-pumping activity in Hep G2 cells. Biochem Biophys Res Commun 250: 374-380, 1998 .

10. Maruyama N, Ishigami A and Kondo Y: Pathophysiological significance of senescence marker protein-30. Geriatr Gerontol Int 10 (Suppl 1): S88-S98, 2010.

11. Ishigami A, Fujita T, Handa S, Shirasawa T,Koseki H, Kitamura T, Enomoto N, Sato N, Shimosawa T and Maruyama N: Senescence marker protein-30 knockout mouse liver is highly susceptible to tumor necrosis factor-alpha- and Fas-mediated apoptosis. Am J Pathol 161: 1273-1281, 2002.

12. Handa S, Maruyama $\mathrm{N}$ and Ishigami A: Over-expression of senescence marker protein-30 decreases reactive oxygen species in human hepatic carcinoma Hep G2 cells. Biol Pharm Bull 32: 1645-1648, 2009.

13. Jung KJ, Ishigami A, Maruyama N, Takahashi R, Goto S, Yu BP and Chung HY: Modulation of gene expression of SMP-30 by LPS and calorie restriction during aging process. Exp Gerontol 39: 1169-1177, 2004

14. Son TG, Kim SJ, Kim K, Kim MS, Chung HY and Lee J: Cytoprotective roles of senescence marker protein 30 against intracellular calcium elevation and oxidative stress. Arch Pharm Res 31: 872-877, 2008.

15. Son TG, Zou Y, Jung KJ, Yu BP, Ishigami A, Maruyama N and Lee J: SMP30 deficiency causes increased oxidative stress in brain. Mech Ageing Dev 127: 451-457, 2006.

16. Yamaguchi $M$ and Ueoka S: Inhibitory effect of calcium-binding protein regucalcin on ribonucleic acid synthesis in isolated rat liver nuclei. Mol Cell Biochem 173: 169-175, 1997.

17. Katsumata $\mathrm{T}$ and Ya'maguchi $\mathrm{M}$ : Inhibitory effect of calcium-binding protein regucalcin on protein kinase activity in the nuclei of regenerating rat liver. J Cell Biochem 71: 569-576, 1998. 
18. Omura M and Yamaguchi M: Regulation of protein phosphatase activity by regucalcin localization in rat liver nuclei. J Cell Biochem 75: 437-445, 1999.

19. Inagaki S and Yamaguchi M: Suppressive role of endogenous regucalcin in the enhancement of protein kinase activity with proliferation of cloned rat hepatoma cells (H4-II-E). J Cell Biochem Suppl (Suppl 36): S12-S18, 2001.

20. Nakagawa T, Sawada N and Yamaguchi M: Overexpression of regucalcin suppresses cell proliferation of cloned normal rat kidney proximal tubular epithelial NRK52E cells. Int J Mol Med 16: 637-643, 2005.

21. Yamaguchi M and Daimon Y: Overexpression of regucalcin suppresses cell proliferation in cloned rat hepatoma H4-II-E cells: Involvement of intracellular signaling factors and cell cycle-related genes. J Cell Biochem 95: 1169-1177, 2005.

22. Jung KJ, Lee EK, Kim SJ, Song CW, Maruyama N, Ishigami A, Kim ND, Im DS, Yu BP and Chung HY: Anti-inflammatory activity of SMP30 modulates NF- $\kappa \mathrm{B}$ through protein tyrosine kinase/phosphatase balance. J Mol Med (Berl) 93: 343-356, 2015.

23. Hasegawa G, Yamasaki M, Kadono M, Tanaka M, Asano M Senmaru T, Kondo Y, Fukui M, Obayashi H, Maruyama N, et al: Senescence marker protein-30/gluconolactonase deletion worsens glucose tolerance through impairment of acute insulin secretion. Endocrinology 151: 529-536, 2010

24. Park H, Ishigami A, Shima T, Mizuno M, Maruyama N, Yamaguchi K, Mitsuyoshi H, Minami M, Yasui K, Itoh Y, et al: Hepatic senescence marker protein-30 is involved in the progression of nonalcoholic fatty liver disease. J Gastroenterol 45: 426-434, 2010

25. Yamaguchi $M$, Igarashi $A$, Uchiyama $S$ and Sawada $N$ : Hyperlipidemia is induced in regucalcin transgenic rats with increasing age. Int J Mol Med 14: 647-651, 2004.

26. Hasegawa G: Decreased senescence marker protein-30 could be a factor that contributes to the worsening of glucose tolerance in normal aging. Islets 2: 258-260, 2010 .

27. Weixia L, Shaojian T, Xia L, Wenjin Z, Linzhi J and Hao L: Comparison of expression levels of senescence marker protein 30 in lens epithelial cells among different ages of cataract patients. Chin J Exp Ophthalmol: 521-524, 2014. (In Chinese).

28. Duan J, Duan J, Zhang Z and Tong T: Irreversible cellular senescence induced by prolonged exposure to $\mathrm{H}_{2} \mathrm{O}_{2}$ involves DNA-damage-and-repair genes and telomere shortening. Int J Biochem Cell Biol 37: 1407-1420, 2005.

29. Livak KJ and Schmittgen TD: Analysis of relative gene expression data using real-time quantitative PCR and the 2(-Delta Delta C(T)) method. Methods 25: 402-408, 2001.

30. Churchill GC and Louis $\mathrm{CF}: \mathrm{Ca}(2+)$ regulation in differentiating lens cells in culture. Exp Eye Res 75: 77-85, 2002.

31. Zm SZ, Khoshaman K, Masoudi R, Hemmateenejad B and Yousefi R: The structural alteration and aggregation propensity of glycated lens crystallins in the presence of calcium: Importance of lens calcium homeostasis in development of diabetic cataracts. Spectrochim Acta A Mol Biomol Spectrosc 170: 174-183, 2016.
32. Li WC, Kuszak JR, Dunn K, Wang RR, Ma W, Wang GM, Spector A, Leib M, Cotliar AM, Weiss M, et al: Lens epithelial cell apoptosis appears to be a common cellular basis for non-congenital cataract development in humans and animals. J Cell Biol 130: 169-181, 1995.

33. Maruno KA, Lovicu FJ, Chamberlain CG and McAvoy JW: Apoptosis is a feature of TGF beta-induced cataract. Clin Exp Optom 85: 76-82, 2002

34. Hammond CJ, Snieder H, Spector TD and Gilbert CE: Genetic and environmental factors in age-related nuclear cataracts in monozygotic and dizygotic twins. N Engl J Med 342: 1786-1790, 2000.

35. McCarty CA and Taylor HR: The genetics of cataract. Invest Ophthalmol Vis Sci 42: 1677-1678, 2001.

36. Ishikawa Y, Hashizume K, Kishimoto S, Tezuka Y, Nishigori H, Yamamoto N, Kondo Y, Maruyama N, Ishigami A and Kurosaka D: Effect of vitamin C depletion on UVR-B induced cataract in SMP30/GNL knockout mice. Exp Eye Res 94: 85-89, 2012.

37. Bhuyan KC, Bhuyan DK and Podos SM: Lipid peroxidation in cataract of the human. Life Sci 38: 1463-1471, 1986.

38. Spector A: Oxidative stress-induced cataract: Mechanism of action. FASEB J 9: 1173-1182, 1995

39. Yao K, Ye P, Zhang L, Tan J, Tang X and Zhang Y: Epigallocatechin gallate protects against oxidative stress-induced mitochondria-dependent apoptosis in human lens epithelial cells. Mol Vis 14: 217-223, 2008.

40. Kleiman NJ, Wang RR and Spector A:Hydrogen peroxide-induced DNA damage in bovine lens epithelial cells. Mutat Res 240: $35-45,1990$.

41. Cristofalo VJ, Lorenzini A, Allen RG, Torres C and Tresini M: Replicative senescence: A critical review. Mech Ageing Dev 125: 827-848, 2004

42. Frippiat C, Chen QM, Zdanov S, Magalhaes JP, Remacle J and Toussaint O: Subcytotoxic $\mathrm{H} 2 \mathrm{O} 2$ stress triggers a release of transforming growth factor-beta 1, which induces biomarkers of cellular senescence of human diploid fibroblasts. J Biol Chem 276: 2531-2537, 2001.

43. Frippiat C, Dewelle J, Remacle J and Toussaint O: Signal transduction in $\mathrm{H} 2 \mathrm{O} 2$-induced senescence-like phenotype in human diploid fibroblasts. Free Radic Biol Med 33: 1334-1346, 2002.

44. Chen JH, Ozanne SE and Hales CN: Methods of cellular senescence induction using oxidative stress. Methods Mol Biol 371: 179-189, 2007. 